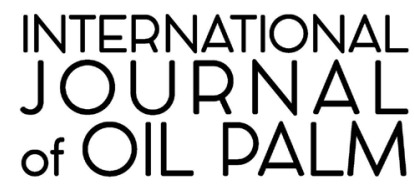

Volume 1, Number 1, January 2018

Page 38-49

ISSN: 2599-3496 print

ISSN: 2614-2376 online

\title{
Gene Expression Analysis of Somatic Embryogenesis in Oil Palm
}

\author{
Nuryanti Syariyanto $^{1^{*}}$, Utut Widyastuti ${ }^{2}$, Nurita Toruan Mathius ${ }^{1}$ \\ 1PT SMART Tbk, Bogor 16180, Indonesia. \\ ${ }^{2}$ Bogor Agricultural University, Bogor 16680, Indonesia.
}

\begin{abstract}
Multiplication of oil palm through somatic embryogenesis is hampered by low callogenesis and embryogenesis rates. Molecular marker based on RNA (transcriptomes analysis) is considered as one of the most effective techniques for detection and differentiation of embryogenic and non-embryogenic callus. A previous research using microarray technique had shown some potential candidate genes related to oil palm somatic embryogenesis, such as: IAA-amino acid hydrolase ILR1-like1 (ilr1), late embryogenesis abundant (lea2), 26S proteasome non-ATPase regulatory subunit 13 homolog B (26sp), and alpha trehalose phosphate synthase [UDP-forming] 6-like (tps6). The objective of this study was to analyze the transcription level of $i l r 1$, lea2, $26 s p$, and tps 6 using quantitative reverse transcription PCR (RT-qPCR). Non-embryogenic nodular callus and somatic embryo (coleoptile stage) of Elaeis guineensis var. Tenera (Deli Dura x AVROS Pisifera) leaf explants were collected from three palms for RNA extraction. The first strand cDNA was synthesized from RNA and used for gene expression analysis. The expressions of four embryogenesis-related genes were analyzed using Relative Quantification Standart Curve method. RQ value was analyzed with One-way ANOVA and Dunnett's test using Statistical Product and Service Solution (SPSS) 20.0 for windows. In RT-qPCR analysis, non-embryogenic nodular callus was used as calibrator sample and $40 \mathrm{~S}$ ribosomal protein S27-2 (40s) was used as reference gene. The result shows that ilr1 and lea2 genes were significantly transcribed higher on coleoptile stage of the somatic embryo compared to callus, in other hand $26 s p$, and tps 6 shows no expression difference on both samples. ilr1 genes gave the highest expression in somatic embryo compared to callus in most tested palms. Thus, it indicated that ilr1 may potentially involve in oil palm somatic embryogenesis and can be used as a candidate to develop the marker for embryogenesis in oil palm.
\end{abstract}

Keywords: Elaeis guineensis, IAA-amino acid hydrolase, RT-qPCR, tissue culture, transcript level analysis

\footnotetext{
${ }^{*}$ Corresponding author :

Biotechnology Department, Plant Production and Biotechnology Division

PT SMART Tbk. (Sinarmas Group), Jalan Raya Cijayanti, Sentul, Bogor 16180, Jawa Barat, Indonesia

E-mail: nuryantisyariyanto@gmail.com
} 


\section{INTRODUCTION}

Oil palm (Elaeis guineensis) is one of the most productive oil-bearing plants in comparison to other oil crops, such as rapeseed, sunflower, and soybean (Sumathi et al. 2008). Palm oil is used in many foods, household products, and biodiesel production. Due to the very high demand for vegetable oils, the increment in palm oil production is needed. It can be achieved by planting elite palms.

Tissue culture is one of the best techniques to multiple elite palms, as it could improve oil yield by $12-15 \%$ through cloning the top $5 \%$ of the palms and $30 \%$ by recloning the top clones after a clonal test (Soh 2012). Nevertheless, this technique is still hampered by low embryogenesis rate. Callogenesis and embryogenesis rates were very low, only about $19 \%$ (Corley \& Tinker 2003) and 3\%, respectively (Kushairi 2010).

Some factors that influence the success of somatic embryogenesis in oil palm are genotype (Sanputawong \& Te-chato 2008), culture media, plant growth regulator, carbon sources (Kramut \& Te-chato 2010), cellular competences, and microculture environment (light $\&$ temperature). In oil palm tissue culture, callogenesis and embryogenesis rate is influenced by different progeny (Nugroho et al. 2014). Genotypic variation of (three dura palms) in response to four auxins (2,4-D, Picloram, 2,4-D + Picloram and NAA) was observed both in callus induction and embryogenesis (Jayanthi et al. 2015). Mostly researchers had only focused to improve the success of embryogenesis through modification of culture media and culture condition.

Understanding of oil palm tissue culture's molecular basis could provide the necessary information needed to improve the efficiency of oil palm propagation, such as identification of genes related to embryogenesis in oil palm. It can be used in developing molecular marker to differentiate the embryogenic and non-embryogenic cultures. Many approaches had been taken to understand the complexities of gene expressions and interactions in oil palm embryogenesis, such as analysis with DNA microarray (Low et al. 2006 and Budinarta et al. 2012), analysis of Expressed Sequence Tags (ESTs) (Lin et al. 2009), and cDNA Amplified Fragment Length Polymorphism (cDNA-AFLP) (Pattarapimol et al. 2015).

Some embryogenesis-related genes in oil palm, such as lipid transfer protein homolog (wbp1a), somatic embryogenesis receptor kinase 1 (serk1), and defensin (egad1) (Shariff et al. 2008), have been reported. Other genes are also reported in carrot and Arabidopsis such as late embryogenesis abundant (lea), somatic embryogenesis receptor kinase (serk), agamous-like 15 (agl15), baby boom ( $(\mathrm{bbm})$, leafy cotyledon 1 (lec1), fusca3 (fus3) and leafy cotyledon 2 (lec2) (lkeda et al. 2006).

Previous research using microarray technique compared non-embryogenic nodular callus with the somatic embryo (Budinarta et al. 2012). This study was used many stages of somatic embryo (globular, coleoptilar, and scutellar) in bulk. The result showed that IAA-amino acid hydrolase ILR1-like 1 (ilr1) gene has the highest transcript levels (fold change is 142.62 up-regulated) in somatic embryo compared to non-embryogenic nodular callus.

Late embryogenesis abundant (lea2) gene have transcript levels 1.93 down-regulated in the somatic embryo (Budinartha et al. 2012). This result is in contrast with Lara-Chaves et al. (2012) result which the transcript levels of LEA gene was accumulated in developing Pinustaeda (pine) embryos and the highest transcript levels were in late cotyledonary phase. 
26S proteasome non-ATPase regulatory subunit 13 homolog $B(26 s p)$ was the same with LEA genes. 26sp had fold change 15.13 down-regulated in somatic embryo compared to callus (Budinartha et al. 2012), but this detected gene had the highest transcript levels in round/globular (embryo) stage in pine.

Trehalose phosphate synthase [UDPforming] 6-like (tps6), also had the transcript levels about 11.44 down-regulated in somatic embryo compared to callus (Budinarta et al. 2012). This gene was one of three genes that had the highest interaction with others genes (embryogenesis-related genes) based on gene interaction analysis with Bioinformatic software Cytoscape_v2.8 and BioGRID 3.2 database based on Budinarta et al. 2012 result.

Thereby, the aim of this study was to analyze the transcripts level of ilr1, lea2, $26 s p$, and tps 6 genes in callus and embryo stage of oil palm using RT-qPCR.

\section{MATERIALS AND METHODS}

\section{Plant Materials}

The samples were obtained from the Tissue Culture Research Laboratory of PT SMART Tbk, West Java Indonesia. Callus (non-embryogenic nodular callus) and somatic embryo (coleoptilar stage) of $E$. guineensis var. Tenera (Deli Dura $x$ AVROS Pisifera) were generated from leaf explants through indirect somatic embryogenesis.

The fresh samples of callus and somatic embryo from three palms of three different progenies (Table 1) were collected prior to RNA extraction. Callus and embryoids were induced from leaf explant with Murashige and Skoog (MS) basal medium incorporated with 2,4-Dichlorophenoxyacetic acid (2,4-D) and Naphthaleneacetic acid (NAA) (Wong et al. 1997).

\section{RNA Extraction and cDNA Synthesis}

Total RNA was isolated from callus and somatic embryos samples using a mortar and liquid nitrogen according to NucleoSpin ${ }^{\circledR}$ RNA Plant Protocol (Macherey-Nagel, Germany) followed by DNAse treatment. Isolated RNA was stored at-80 ${ }^{\circ} \mathrm{C}$.

The quality and quantity of RNA were determined using NanoDrop ${ }^{\mathrm{TM}}$ 2000c Spectrophotometer (Thermo Scientific, USA). Ten microliters of RNA samples was verified on denaturing Formaldehyde gels in 1X MOPS buffer (Mansour \& Pestov 2013), ran at 100 volts for 30 min followed by EtBr staining, and documented using the UV trans-illuminator Gel-Doc ${ }^{\mathrm{TM}}$ XR (BIORAD, USA). Two hundred nanogram of total RNA was assessed for its integrity on capillary electrophoresis using QIAxcel RNA QC Kit v2.0 protocol (Qiagen, Germany) followed by RNA quantification by RNA Integrity Score (RIS) using QIAxcel ScreenGel Software 1.2 (Qiagen, Germany).

The first strand of cDNA was synthesized from $3 \mu \mathrm{g}$ of RNA ( $1 \mu \mathrm{g}$ for each reaction) following the QuantiTect ${ }^{\circledR}$ Reverse Transcription Kit protocol (Qiagen, Germany). To assess the purity of cDNA from DNA contamination, amplification using forward primer 40s-1 5'GCTCCTTCCCTTCCTCTCAA'3 and reverse primer 40s-1 5'CCTGGACTAACAAAATCACCGAT'3 was performed. This primer is intron-spanning primers that will generate the product size of about $456 \mathrm{bp}$ for cDNA and \pm 1000 bp for DNA. The cDNA samples were stored at $-40{ }^{\circ} \mathrm{C}$.

\section{Construction of Standard Curve}

The cDNA of callus was amplified with RT-qPCR primers (Table 2). Reaction mix was as followed: $1 \mu \mathrm{L}$ of cDNA $(1.5 \mu \mathrm{g}$ $\left.\mu \mathrm{L}^{-1}\right) ; 14 \mu \mathrm{L}$ of primer mix $(10 \mu \mathrm{M}) ; 10.5$ $\mu \mathrm{L}$ of $10 \mathrm{X}$ DreamTaq Buffer; $10.5 \mu \mathrm{L}$ of 
Table 1 Origin information and embryogenesis rate of samples

\begin{tabular}{cllll}
\hline Palm No. & Progeny & Female & Male & (\%) Embryo \\
\hline 1 & $9810093 \mathrm{~N}$ & Deli dura 5005.126 & AVROS pisifera 742.316 & 5.6 \\
2 & $9010190 \mathrm{E}$ & Deli dura 711.614 & AVROS pisifera 742.316 & 6.7 \\
3 & $9102109 \mathrm{E}$ & Deli dura 703.802 & AVROS pisifera 742.316 & 3.2 \\
\hline
\end{tabular}

Table 2 Primer sets used for RT-qPCR

\begin{tabular}{|c|c|c|c|c|c|c|}
\hline $\begin{array}{l}\text { Gene } \\
\text { abbreviation }\end{array}$ & Primer pair $5^{\prime} \rightarrow 3^{\prime}$ & $\begin{array}{l}\text { Product } \\
\text { size } \\
\text { (bp) }\end{array}$ & $\begin{array}{c}\mathrm{Ta} \\
\left({ }^{\circ} \mathrm{C}\right)^{*}\end{array}$ & Description & E-value & $\begin{array}{l}\text { Ident } \\
(\%)\end{array}$ \\
\hline ilr1 & $\begin{array}{l}\text { F CTCCTCAATTCGTTGCTTCAGTT } \\
\text { R CGGAAAGGGAGGTCATGGT }\end{array}$ & 250 & 64 & $\begin{array}{l}\text { PREDICTED: } E \text {. } \\
\text { guineensis IAA- } \\
\text { amino acid hydrolase } \\
\text { ILR1-like } 1 \\
\text { (LOC105047633) }\end{array}$ & 8.0E-82 & 99 \\
\hline lea2 & $\begin{array}{l}\text { F ACAAACCCCAATCCCATCC } \\
\text { R AATCGGCACATCAACAATGAG }\end{array}$ & 243 & 64 & $\begin{array}{l}\text { PREDICTED: } \\
\text { E. guineensis } \\
\text { uncharacterized } \\
\text { (LOC105049817) }\end{array}$ & 7.0E-93 & 100 \\
\hline $26 s p$ & F AGCCTCTCGGTTCATCTTATTG & 250 & 62 & $\begin{array}{l}\text { PREDICTED: } E \text {. } \\
\text { guineensis } 26 S \\
\text { proteasome non- } \\
\text { ATPase regulatory } \\
\text { subunit } 13 \text { homolog B } \\
\text { (LOC105060648) }\end{array}$ & 4.0E-90 & 100 \\
\hline tps6 & F CAGGAGAGGGGCTTATCACC & 240 & 64 & $\begin{array}{l}\text { PREDICTED: E. } \\
\text { guineensis alpha- } \\
\text { trehalose-phosphate } \\
\text { synthase } \\
\text { [UDP-forming] 6-like } \\
\text { (LOC105048485) }\end{array}$ & $\begin{array}{l}4.0 \mathrm{E}- \\
85\end{array}$ & 100 \\
\hline $40 s$ & 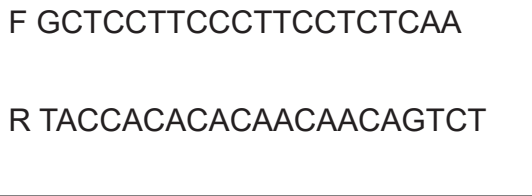 & 246 & 62 & $\begin{array}{l}\text { PREDICTED: } \\
\text { E. guineensis } \\
40 \text { S ribosomal } \\
\text { protein S27-2 } \\
\text { (LOC105035175) }\end{array}$ & 2.0E-98 & 100 \\
\hline
\end{tabular}

${ }^{*} \mathrm{Ta}\left({ }^{\circ} \mathrm{C}\right)$ is annealing temperature of primers which were optimized with enzyme DreamTaq DNA Polymerase (Thermo Scientific, USA).

dNTP Mix, $2 \mathrm{mM}$ each; $4.2 \mu \mathrm{L}$ of $\mathrm{MgCl}_{2}$; and $0.84 \mu \mathrm{L}$ of DreamTaq DNA Polymerase (Thermo Scientific, USA), and nuclease-free water was added to reach the total volume of $100 \mu \mathrm{L}$.

The PCR program was at $94{ }^{\circ} \mathrm{C}$ for 5 min; 35 cycles of $94{ }^{\circ} \mathrm{C}$ for 1 min (denaturation), 62 or $64{ }^{\circ} \mathrm{C}$ for $30 \mathrm{~s}$ (Table 2) (annealing), $72{ }^{\circ} \mathrm{C}$ for $1 \mathrm{~min}$ (extension), and $72{ }^{\circ} \mathrm{C}$ for $7 \mathrm{~min}$ (final synthesize). The amplified products were separated on $2 \%$ agarose gel, $100 \mathrm{~V}$ for $90 \mathrm{~min}$. The PCR products were extracted from the gel and purified using QiAquick ${ }^{\circledR}$ Gel Extraction Kit (Qiagen, Germany).

The standard curve was conducted by two replications with ten fold dilutions of the purified PCR product (CDNA), ranging from $10-1 n g \mu L^{-1}-10^{-7} n g \mu L^{-1}$. All of the RT-qPCR assays showed a linear relationship between $C_{t}$ value and the log of cDNA concentration $\left(R^{2}>0.95\right)$ in all cases, which allowed concentration determination of the unknown samples based on their $\mathrm{C}_{t}$ value. 


\section{Relative Quantification}

The expressions of four embryogenesis-related genes were analyzed using Relative Quantification Standart Curve method (Larionov et al. 2005). In this study, was compared the transcription level of two samples: non-embryogenic nodular callus with the somatic embryo, while the non-embryogenic nodular callus used as samples calibrator. This study also analyzes transcription level of four embryogenesis-related genes such as ilr1, lea, 26sp, and tps6.

In this study, RT-qPCR analysis used $40 S$ ribosomal protein S27-2 (40s) as reference gene (Chan et al. 2014). 40s selected used after analyze five reference genes: act3, ef2, 40s, sodm, and tub $\beta 1$. Melting curve analysis showed that three genes: act3, 40s, and sodm was specific (no dimer) (Figure 1). 40s selected as Breference genes for RT-qPCR analysis because these reference genes have the most stable of $\mathrm{C}_{t}$ value on both tested samples (Table 3 ).

The RT-qPCR primers were designed using the Primer-Blast software (Ye et al. 2012) that generated amplicon with the size of 240-250 bp (Table 2). Primers were designed according to Wang and Seed (2006). PCR product was sent for sequencing to the $1^{\text {st }}$ BASE (IDT, Singapore). Sequences analysis was carried out using Basic Local Alignment Search Tool Nucleotide (BLASTN) and BLASTX from the National Center for Biotechnology Information (NCBI) server (http://www. ncbi.nih.gov) (Altschul et al. 1997).
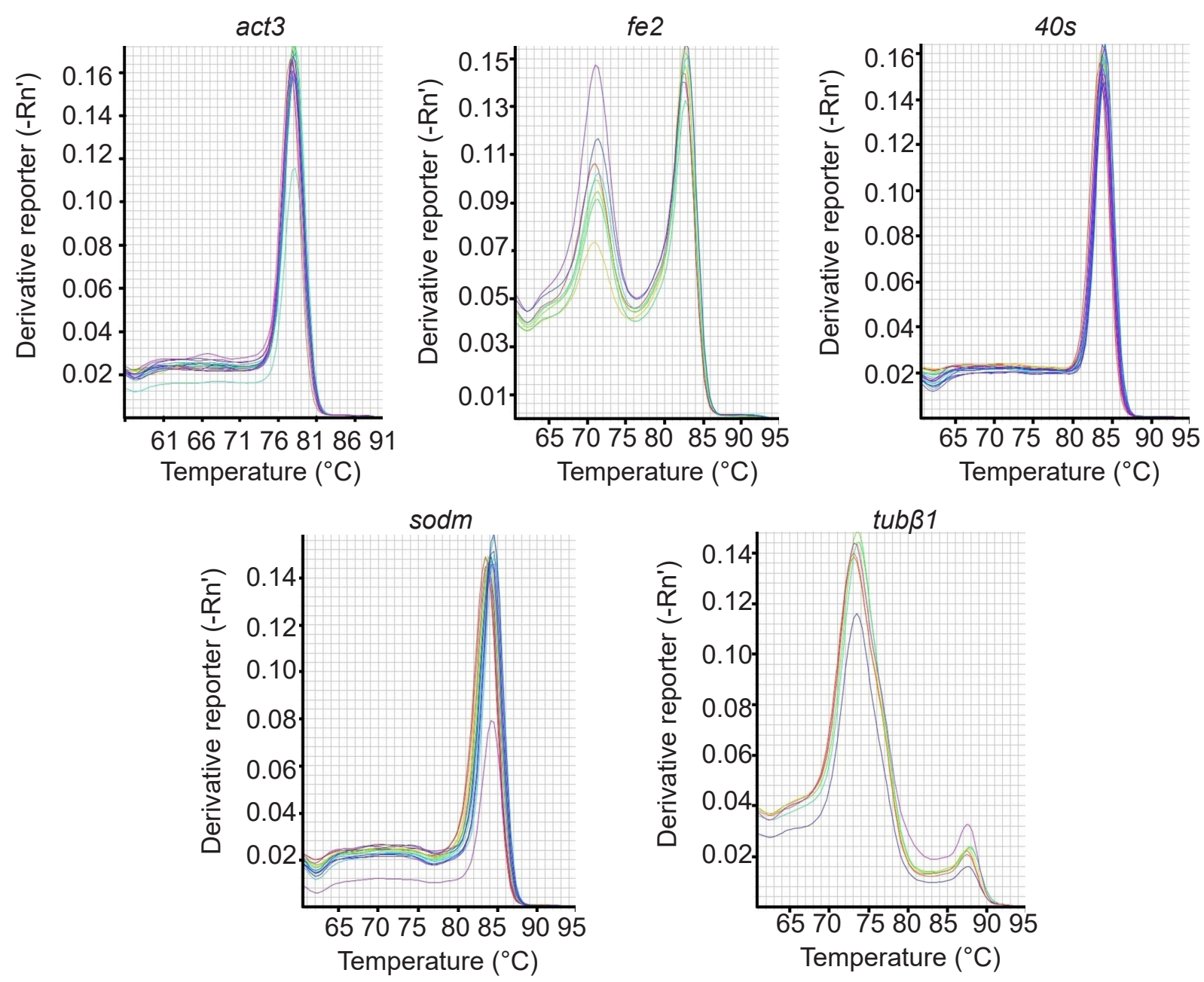

Figure 1 Melting curve analysis on five reference gene used oil palm embryo 
Table 3 Coefficient of variation of three reference gene on callus and embryo

\begin{tabular}{lllccc}
\hline Gene & Samples & C $_{\mathrm{t}}$ Range $^{*}$ & SD of $_{\mathrm{t}}$ & Mean of C $_{\mathrm{t}}$ & $\mathrm{CV}(\%)$ \\
\hline \multirow{2}{*}{ act3 } & Callus & $26.65-29.84$ & 1.160 & 27.999 & 4.145 \\
& Embryo & $25.05-27.64$ & 0.994 & 26.514 & 3.748 \\
\multirow{2}{*}{$40 \mathrm{~s}$} & Callus & $27.35-29.28$ & 0.850 & 28.240 & 3.010 \\
& Embryo & $26.79-29.70$ & 1.084 & 28.215 & 3.840 \\
\multirow{2}{*}{ Sodm } & Callus & $30.90-34.99$ & 1.660 & 32.244 & 5.148 \\
& Embryo & $29.96-33.28$ & 1.378 & 31.555 & 4.366 \\
\hline
\end{tabular}

${ }^{*} \mathrm{RT}$-qPCR analysis used five replicate for each samples.

A triplicate $\mathrm{RT}$-qPCR reaction was performed on MicroAmp ${ }^{\circledR}$ Fast Optical 96well reaction plate $0.1 \mathrm{~mL}$ (Applied Biosystems, USA) using QuantiFast ${ }^{\circledR} \mathrm{SYBR}^{\circledR}$ Green PCR Kit (Qiagen, USA) and Applied Biosystems ${ }^{\mathrm{TM}} 7500$ Fast Real-Time PCR System. RT-qPCR reactions were as followed: $200 \mathrm{ng} \mu \mathrm{L}^{-1}$ cDNA samples, 0.2 $\mu \mathrm{M}$ primer mix, $5 \mu \mathrm{L}$ QuantiFast SYBR Green PCR Master Mix (2x), and RNasefree water to reach the total volume of $10 \mu \mathrm{L}$ with PCR condition: pre-cycling 95 ${ }^{\circ} \mathrm{C}$ for $5 \mathrm{~min}$, cycling stage $95^{\circ} \mathrm{C}$ for 10 $\mathrm{s}$ (denaturation) and $62{ }^{\circ} \mathrm{C}$ for $30 \mathrm{~s}$ (annealing and extension). The amplification was done for 40 cycles and Melting curve analysis was conducted at $95^{\circ} \mathrm{C}$ for $15 \mathrm{~s}$, $60{ }^{\circ} \mathrm{C}$ for $1 \mathrm{~min}, 95^{\circ} \mathrm{C}$ for $15 \mathrm{~s}$, and $60^{\circ} \mathrm{C}$ for $15 \mathrm{~s}$.

The expressions of four target genes using RT-qPCR by manual reaction setup were assessed with three biological replications (three palms) and triplicate technical replication (each palm three times RNA sample extraction). Standard curve and $C_{t}$ were used for normalization, while quantity value was calculated automatically with 7500 Software v2.0.6 (Applied Biosystems, USA). Relative Quantification $(R Q)$ value was calculated according to Real-Time Quantitative PCR guide from Applied Biosystems (2008). RQ value was analyzed with One-way ANOVA and Dunnett's test using Statistical Product and Service Solution (SPSS) 20.0 for windows. $R Q$ value was calculated following this equation:

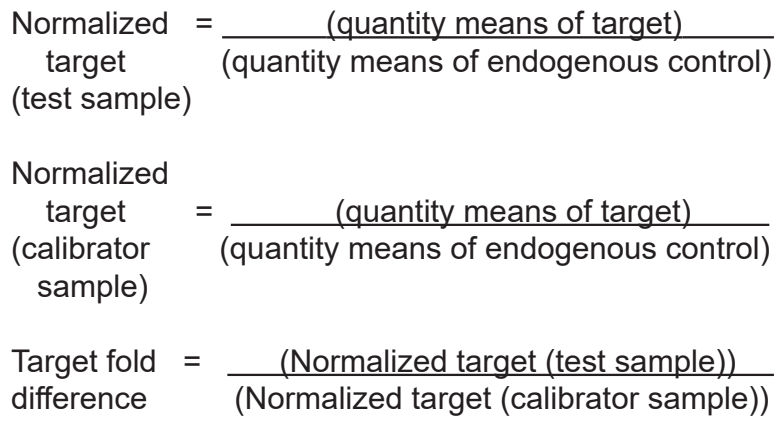

\section{RESULTS AND DISCUSSION}

RNA was isolated from callus (nodular callus) and somatic embryos (coleoptilar stage) of E. guineensis var. Tenera (Deli Dura $x$ AVROS Pisifera) from three different palm trees. A High quality of RNA has an $O D_{260 / 280}$ value with the ratio ranging from 1.8 to 2.0 (Sambrook et al. 1989), and had higher than five RNA Integrity Number (RIN/RQI) (Fleige \& Pfaffl 2006). Concentration, purity and integrity score of RNA samples are shown on Table 4. The first strand of cDNA was synthesized from RNA using QuantiTect ${ }^{\circledR}$ Reverse Transcription Kit (Qiagen, Germany). Figure 2 shows that cDNA with primer $40 s-1$ amplification is free from DNA contamination and generated $\mathrm{PCR}$ product with the size of $\pm 456 \mathrm{bp}$, while the DNA produce band with the size of $\pm 1000 \mathrm{bp}$.

The four embryogenesis-related genes were analyzed on callus and somatic embryo using Relative Quantification Standart Curve method (Larionov et al. 2005). This method remains a reliable and simple alternative to the PCR-efficiency based 
Table 4 Quantity and quality of RNA isolated from callus and somatic embryo of oil palm culture

\begin{tabular}{|c|c|c|c|c|c|c|c|c|}
\hline \multirow[b]{2}{*}{ Samples } & \multicolumn{4}{|c|}{ Callus } & \multicolumn{4}{|c|}{ Somatic embryo } \\
\hline & Code* & $\begin{array}{c}\text { [RNA] ng } \\
\mu \mathrm{L}^{-1}\end{array}$ & $A_{260 / 280}$ & RIS & Code* & $\begin{array}{c}\text { [RNA] ng } \\
\mu \mathrm{L}^{-1}\end{array}$ & $\mathrm{~A}_{260 / 280}$ & RIS \\
\hline \multirow{3}{*}{ Palm 1} & C1 & 1225.2 & 2.03 & 4.8 & $\mathrm{E} 1$ & 1002.3 & 2.15 & 5.3 \\
\hline & $\mathrm{C} 2$ & 1593.6 & 2.14 & 4.5 & E2 & 1458.0 & 2.16 & 5.4 \\
\hline & $\mathrm{C} 3$ & 1455.8 & 2.12 & 5.5 & E3 & 1438.6 & 2.15 & 5.8 \\
\hline \multirow{3}{*}{ Palm 2} & C1 & 685.1 & 2.10 & 4.7 & E1 & 391.6 & 2.14 & 5.8 \\
\hline & $\mathrm{C} 2$ & 1714.6 & 2.15 & 5.1 & E2 & 971.9 & 2.15 & 5.4 \\
\hline & C3 & 1109.2 & 2.15 & 4.5 & E3 & 1201.2 & 2.16 & 5.3 \\
\hline \multirow{3}{*}{ Palm 3} & $\mathrm{C} 1$ & 878.6 & 2.16 & 6.5 & $\mathrm{E} 1$ & 1308.8 & 2.15 & 5.7 \\
\hline & $\mathrm{C} 2$ & 1738.0 & 2.14 & 5.2 & E2 & 649.4 & 2.14 & 5.4 \\
\hline & C3 & 1041.1 & 2.08 & 5.1 & E3 & 608.1 & 2.15 & 5.0 \\
\hline
\end{tabular}

${ }^{*} \mathrm{C}$ is callus and $\mathrm{E}$ is somatic embryo.

C1 Palm 1, C2 Palm 2, and C2 Palm 3 selected as calibrator samples and used to construct the standard curve. All somatic embryo used as target samples in RT-qPCR analysis.

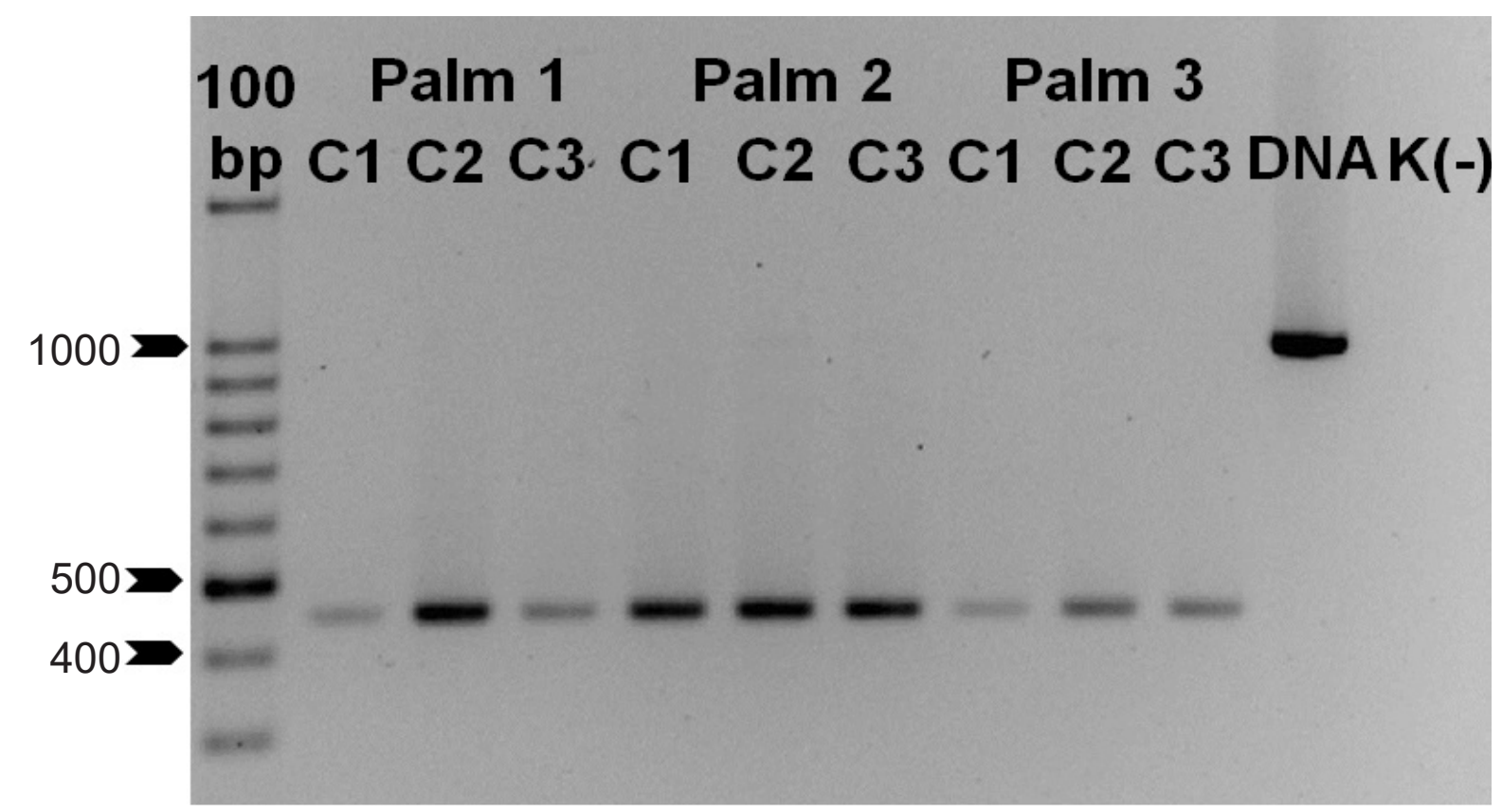

Figure 2 Amplification of 40 s-1 gene on cDNA and DNA callus.

on calculations in relative Real-Time PCR (Larionov et al. 2005). Amplification of all primers had generated single band, which was sent for sequencing. Alignment with BLAST (BLASTN) showed high identity with $E$. guineensis genes (Table 2) and a single peak was observed after Melting curve analysis (Figure 3 ).

The result from RT-qPCR analysis showed that transcription level of ilr1 was mostly higher in somatic embryo (coleop- tile stage) than non-embryogenic nodular callus (calibrator samples) in every palm (Figure 4). Embryo Palm 1 and 2 was significant difference at $p<0.05$ (base on One-way Anova and Dunnett t-tests).

Embryo from Palm 2 gave the highest expression than embryo from two other palms. It indicated that every palm have different endogenous auxin levels. The high expression of ilr1 gene was also reported in the previous research using 


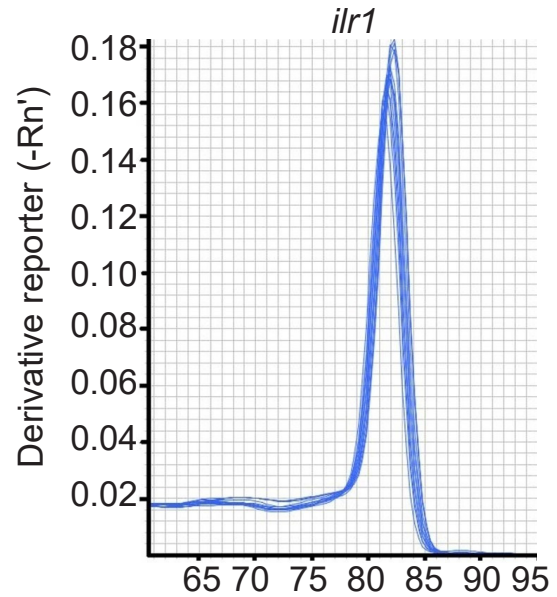

Temperature $\left({ }^{\circ} \mathrm{C}\right)$

$26 s p$

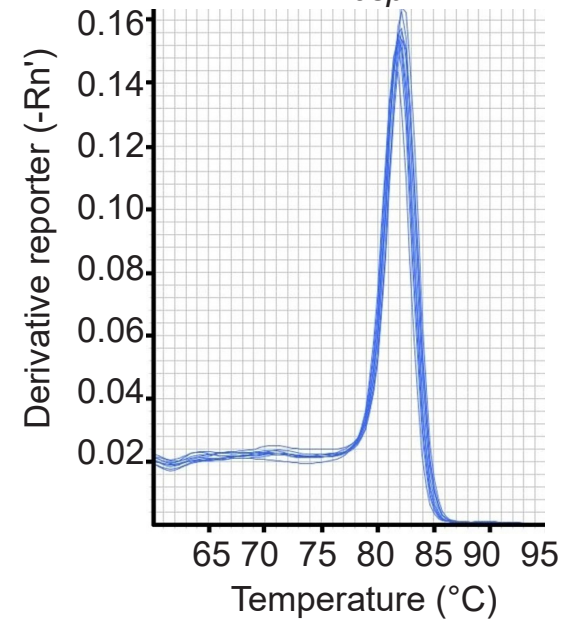

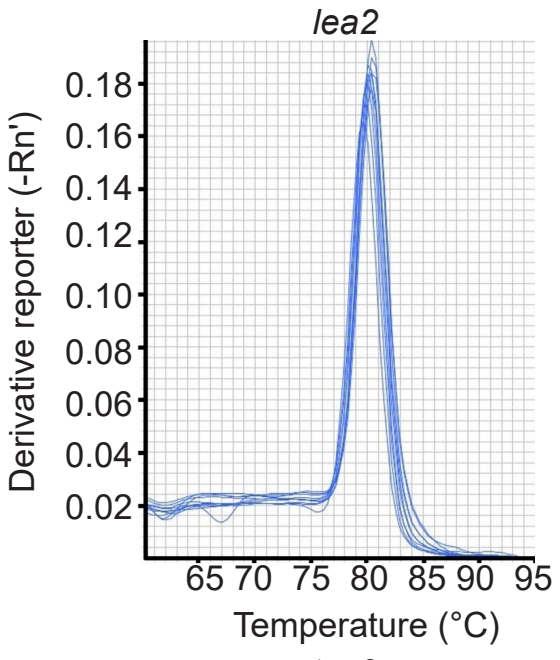

tps6

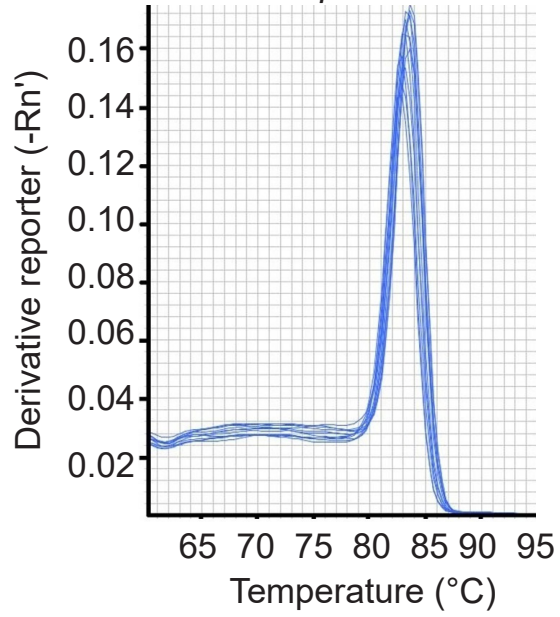

Figure 3 Melting curve analysis on four target genes (ilr1, lea2, 26sp, and tps6).

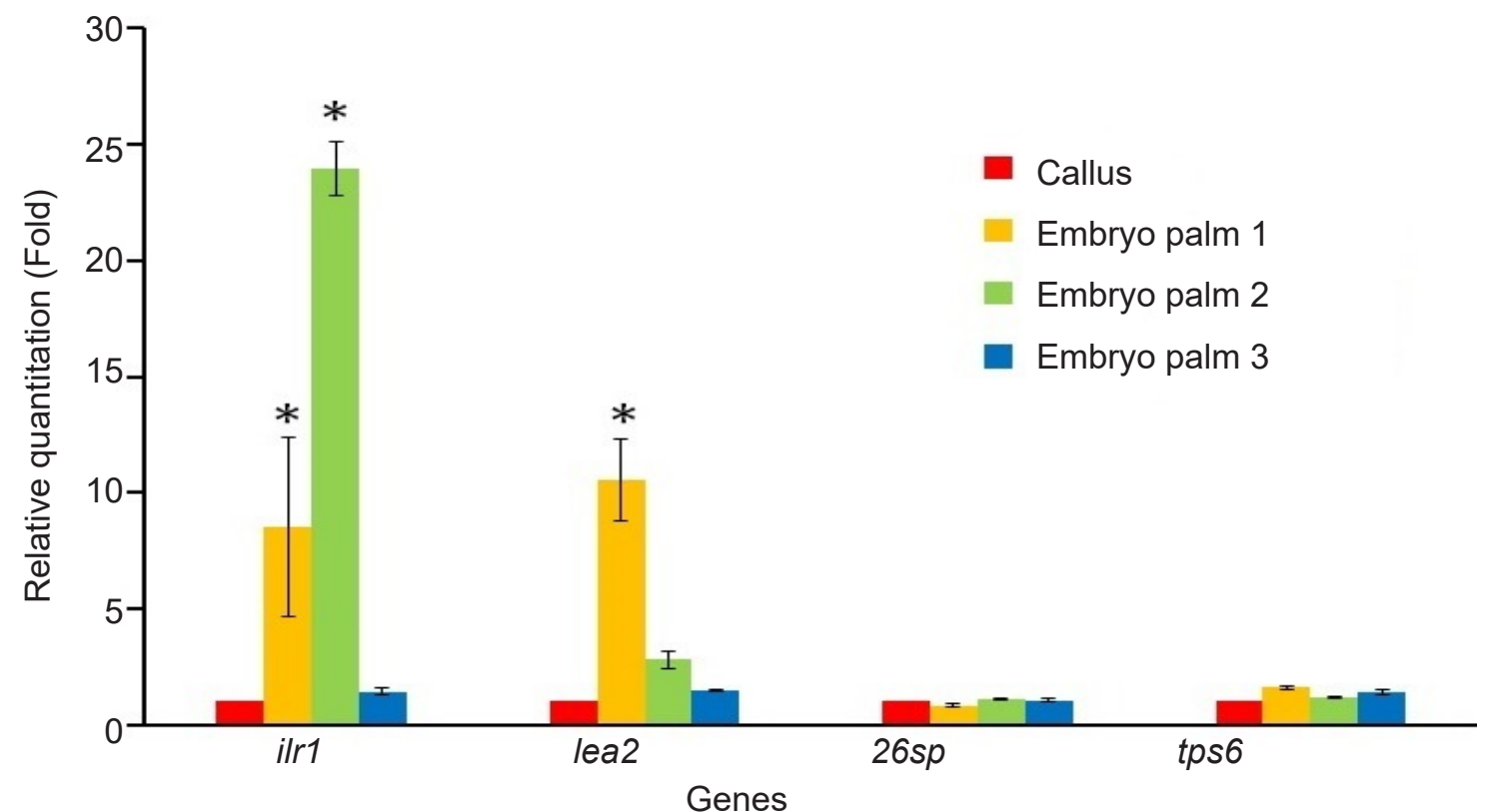

Figure 4 Transcription level analysis result (RQ value) of $i l r 1$, lea2, $26 s p$, and $\operatorname{tps} 6$ on callus and somatic embryo. 
microarray analysis by Budinarta et al. (2012) which in that study, ilr1 142.63 fold up-regulated in somatic embryos compared to callus (Table 5 ).

IAA-amino acid hydrolase ILR1-like1 (ilr1) include in IAA-conjugates. This type of auxin hydrolase converted IAA conjugates to active IAA through tryptophan-independent pathways of IAA biosynthesis in plants (Bartel 1997). Auxin had emerged as one of the potent initiators of somatic embryogenesis (Raghavan 1997). Common synthetic auxin such as 2,4-dichlorophenoxyacetic acid (2,4-D) was used for inducing somatic embryogenesis in this study. The hormone generates DNA hypermethylation, which maintains a highly active mitotic stage, and induces pro-embryonic phase in the cells (Endress 1994).

Transcription level analysis showed that late embryogenesis abundant (lea2) gene was expressed higher in somatic embryo than callus, especially in the embryo from Palm 1 (Figure 4). In pine, lea was expressed either in somatic embryo or zygotic embryo and the expression increased simultaneously within embryo development (Lara-Chavez et al. 2012). LEA, a group of hydrophilic proteins, has been linked to plants and animals survival in periods of stress, putatively through the safeguarding of enzymatic function and prevention of aggregation in times of dehydration/heat (Amara et al. 2014). Late embryogenesis abundant proteins (LEA proteins) were first found in cotton (Gossypium hirsutum) seeds, accumulating in late embryogenesis (Dure et al. 1981).

The transcription level of $26 s p$ result showed that no significant expression difference on callus nor somatic embryoid stage. Moreover, some of the embryoids (embryo from Palm 1) were down-regulated (Figure 4), which was also reported in the previous research (26sp have fold change 15.13 down-regulated in embryo compared to callus) using microarray analysis (Budinarta et al. 2012). 26S proteasome non-ATPase regulatory subunit 13 homolog $B(26 s p)$ protein, involves in a wide range of processes, including embryogenesis, hormone signaling, and senescence (Moon et al. 2004). In pine, this gene was also expressed in somatic and zygotic embryos, with the higher expression in globular stage compared to others, such as early and late cotyledonary (LaraChavez et al. 2012).

The transcription level of tps 6 result also showed no significant expression difference in both callus and somatic embryo (Figure 4). This gene is one of the genes that involve in synthesis trehalose in the plant. Trehalose (a-D-glucopyranosyl-[1,1]-a-D-glucopyranoside) is a stable non-reducing sugar, widely found in living cells of bacteria, archaea, fungi, invertebrates, and plants (Avonce et al. 2006). In the plant, trehalose synthesis takes in twosteps: 1 . Synthesis the trehalose-6-phos-

Table 5 Expression of four embryogenesis-related genes through microarray analysis

\begin{tabular}{|c|c|c|c|c|}
\hline No & & Genes & Fold change* & References \\
\hline 1 & ilr1 & $\begin{array}{l}\text { iaa-amino acid hydrolase } \\
\text { ilr1-like } 1\end{array}$ & 142.63 Up & $\begin{array}{l}\text { Chugh and Khurana } \\
2002\end{array}$ \\
\hline 2 & lea2 & $\begin{array}{l}\text { late embryogenesis abundant } \\
\text { protein }\end{array}$ & 1.93 Down & Lara-Chavez et al. 2012 \\
\hline 3 & $26 s p$ & $\begin{array}{l}26 \text { s proteasome non-atpase } \\
\text { regulatory subunit } 13\end{array}$ & 15.13 Down & $\begin{array}{l}\text { Lara-Chavez et al. } \\
2012\end{array}$ \\
\hline & tps6 & $\begin{array}{l}\text { Trehalose-6-phosphate } \\
\text { synthase }\end{array}$ & 11.44 Down & $\begin{array}{l}\text { Eastmond \& Graham } \\
2002\end{array}$ \\
\hline
\end{tabular}

*Fold change values based on microarray result by Budinarta et al. 2012. 
phate (T6P) from sucrose through catalyzed by trehalose-6-phosphate synthase (TPS) and 2. T6P was consecutive dephosphorylation through catalyzed by trehalose-6-phosphate phosphatase (TPP) to produce trehalose (Ponnu et al. 2011).

Trehalose-6-phosphate synthase is essential for the embryo development and maturation of $A$. thaliana (Eastmond \& Graham 2003). Trehalose is an osmoprotectant, which counteracts the desiccation effect of drought, salt, or low-temperature stresses in the basal lineages of life (Crowe et al. 1992). T6P plays an important role in orchestrating cell cycle activity and cell wall biosynthesis with cellular metabolism during embryo development (Gomez et al. 2006).

\section{CONCLUSION}

This study analyzed four embryo-genesis related genes: IAA-amino acid hydrolase ILR1-like1 (ilr1), late embryogenesis abundant (lea2), 26S proteasome non-ATPase regulatory subunit 13 homolog $B$ (26sp), and alpha trehalose phosphate synthase [UDP-forming] 6-like (tps6). The transcription level result showed that ilr1 and lea2 genes were expressed higher on coleoptile stage of the somatic embryo compared to (non-embryogenic nodular) callus. The result also showed that $26 s p$ and tps 6 had no expression difference in both tested samples. ilr1 genes gave the highest expression in somatic embryo compared callus in most tested palms and these genes may potentially be involved in oil palm somatic embryogenesis and can be used as a candidate to develop the marker for embryogenesis in oil palm.

\section{ACKNOWLEDGEMENT}

This project was fully funded by PT SMART Tbk. The authors would like to express their great appreciation to the
Director of Plant Production and Biotechnology Division for permission to publish this article. Authors are also thank to Hadi Septian Guna Putra for statistical data analysis; Zulfikar Achmad Tanjung for Bioinformatic data analysis; Condro Utomo, Roberdi, Reno Tryono, Widyah Budinarta, Shelomi Angeli Karmorahardjo and Rini Yuliana for reviewing the manuscripts and valuable suggestions.

\section{REFERENCES}

Altschul SF, Madden TL, Schaffer AA, Zhang J, Zhang Z, Miller W, Lipman DJ. 1997. Gapped BLAST and PSI-BLAST: A new generation of protein database search programs. Nucleic Acids Res. 25:3389-3402.

Amara I, Zaidi I, Masmoudi K, Ludevid MD, Pages M, Goday A, Brini F. 2014. Insights into late embryogenesis abundant (LEA) proteins in plants: From structure to the functions. Amer J Plant Sci. 5:3440-3455.

Applied Biosystems. 2008. Guide to Performing Relative Quantitation of Gene Expression Using Real-Time Quantitative PCR. California (US): Applied Biosystems.

Avonce N, Mendoza-vargas A, Morett E, Iturriaga G. 2006. Insights on the evolution of trehalose biosynthesis. BMC Evol Biol. 109:1-15.

Bartel B. 1997. Auxin biosynthesis. Annu Rev Plant Biol. 48:51-66.

Budinarta W, Hatorangan MR, Joanito I, Widyartini, Tanjung ZA, Toruan-Mathius N. 2012. Technical Annual Report of Tissue culture and Biotechnology 2012. Bogor (ID): PT SMART Tbk.

Chan PL, Rose RJ, Abdul Murad AM, Zainal Z, Low ET, Ooi LC, Ooi SE, Yahya S, Singh R. 2014. Evaluation of reference genes for quantitative real-time PCR in oil palm elite planting materials propagated by tissue culture. 
PloS one. 9(6):1-13. DOI:10.1371/journal.pone.0099774.

Chugh A, Khurana P. 2002. Gene expression during somatic embryogenesis. Curr Sci. 83(6):715-730.

Corley RHV, Tinker PBH. 2003. The oil palm $4^{\text {th }}$. Malden (US): Wiley.

Crowe JH, Hoekstra FA, Crowe LM. 1992. Anhydrobiosis. Annu Rev Physiol. 54:579-599.

Dure L, Greenway SC, Galau GA. 1981. Developmental biochemistry of cottonseed embryogenesis and germination: changing messenger ribonucleic acid populations as shown by in vitro and in vivo protein synthesis. Biochemistry. 20:4162-4168.

Eastmond PJ, Graham IA. 2003. Trehalose metabolism: a regulatory role for trehalose-6-phosphate. Curr Opin Plant Biol. 6:231-235.

Endress R. 1994. Plant Cell Biotechnology. Berlin Heidelberg (NY): Springer.

Fleige S, Pfaffl MW. 2006. RNA integrity and the effect on the real-time qRT-PCR performance. Mol Asp Med. 27:126-139.

Gomez LD, Baud S, Gilday A, Li Y, Graham IA. 2006. Delayed embryo development in the Arabidopsis Trehalose-6-phosphate synthase 1 mutant is associated with altered cell wall structure, decreased cell division and starch accumulation. Plant J. 46:69-84.

Ikeda M, Umehara M, Kamada H. 2006. Embryogenesis-related genes; Its expression and roles during somatic and zygotic embryogenesis in carrot and Arabidopsis [Review]. Plant Biotech. 23(2):153-161. DOI:10.5511/plantbiotechnology.23.153.

Jayanthi M, Susanthi B, Mohan NM, Mandal PK. 2015. In vitro somatic embryogenesis and plantlet regeneration from immature male inflorescence of adult dura and tenera palms of Elaeis guineensis Jacq. Springer Plus. 4:256.
Kramut P, Te-chato S. 2010. Effect of culture media, plant growth regulators and carbon sources on establishment of somatic embryo in suspension culture of oil palm. J Agricul Tech. 6:159-170.

Kushairi A, Tarmizi AH, Zamzuri I, Ong-Abdullah M, Samsul Kamal R, Ooi SE, Rajanaidu N. 2010. Production, performance and advances in oil palm tissue culture. In: Wong CK, editor. Proceedings of the International Society for Oil Palm Breeders. In International Seminar on Advances in Oil Palm Tissue Culture. ISOPB. p. 1-23.

Lara-Chavez A, Egertsdotter U, Flinn BS. 2012. Comparison of gene expression markers during zygotic and somatic embryogenesis in pine. Vitro Cell Dev Biol Plant. 48(3):341-354. DOI:10.1007/s11627-012-9440-5.

Larionov A, Krause A, Miller W. 2005. A standard curve based method for relative real time PCR data processing. BMC Bioinfo. 6(1):62. DOI:10.1186/1471-2105-6-62.

Lin HC, Morcillo F, Dussert S, Tranchant-Dubreuil C, Tregear JW, Tranbarger TJ. 2009. Transcriptome analysis during somatic embryogenesis of the tropical monocot Elaeis guineensis: Evidence for conserved gene functions in early development. Plant Mol Biol. 70(1-2):173-192. DOI:10.1007/s11103009-9464-3.

Low E, Tan J, Chan P, Boon S, Wong Y, Rozana R, Ooi L, Ma L, Ong-Abdullah M, Cheah S. 2006. Developments toward the application of DNA chip technology in oil palm tissue culture. J Oil Palm Res. Special Issue April:87-98.

Machery-Nagel. 2014. RNA isolation from plant User Manual NucleoSpin ${ }^{\circledR}$ RNA Plant. Germany (DE): Macherey-Nagel $\mathrm{GmbH} \&$ Co.KG.

Mansour FH, Pestov DG. 2013. Separation of long RNA by agarose-formaldehyde gel electrophoresis. Anal Bio- 
chem. 441(1):18-20. DOI:10.1016/j. ab.2013.06.008.

Moon J, Parry G, Estelle M. 2004. The ubiquitin-proteasome pathway and plant development. Plant cell. 16(12):31813195. DOI:10.1105/tpc.104.161220.

Nugroho YA, Sumertajaya IM, Wiendi NM, Toruan-Mathius N. 2014. Estimation of genetic parameters for in vitro culture traits and selection best progenies for Tenera oil palm tissue culture. Energy Procedia. 47:316-22.

Pattarapimol T, Thuzar M, Vanavichit A, Tragoonrung S, Roytrakul S, Jantasuriyarat C. 2015. Identification of gene involved in somatic embryogenesis development in oil palm (Elaeis guineensis Jacq.) using cDNAAFLP. J Oil Palm Res. 27:1-11.

Ponnu J, Wahl V, Schmid M. 2011. Trehalose-6-phosphate: Connecting plant metabolism and development. Frontiers Plant Science. 2:70. DOI:10.3389/ fpls.2011.00070.

Raghavan V. 1997. Molecular embryology of flowering plants. Cambrige (UK): Cambridge University.

Sambrook J, Fristsch EF, Maniatis T. 1989. Molecular Cloning, A Laboratory Manual. $2^{\text {nd }}$ ed. New York (NY): Cold Spring Harbor Laboratory Press.
Sanputawong S, Te-chato S. 2008. Effect of genotypes of oil palm as indicator for speed of callus and embryogenic callus formation. J Agr Tech. 4:147-156.

Shariff EM, Low ETL, Alias H, Choo CS, Singh R. 2008. Identification of genes expressed in the embryoid tissue of oil palm (Elaeis guineensis Jacq.) tissue culture via expressed sequence tag analysis. J Oil Palm Res. 20:51-63.

Soh A. 2012. The future of oil palm clones in Malaysia. J Oil Palm Environ. 3:9397. DOI:10.5366/jope.2012.09.

Sumathi S, Chai SP, Mohamed AR. 2008. Utilization of oil palm as a source of renewable energy in Malaysia. Ren Sustain Eng Rev. 12:2404-2421.

Wang X, Seed B. 2006. High-throughput primer and probe design. In: Dorak MT, editor. Real-time PCR, Taylor and Francis. England (UK): Newcastle-upon-Tyne. p. 93-106.

Wong G, Tan CC, Soh AC. 1997. Large Scale Propagation of Oil Palm Clones-Experiences Todate. Acta Hort. 447:649-658.

Ye J, Coulouris G, Zaretskaya I, Cutcutache I, Rozen S and Madden TL. 2012. Primer-BLAST: a tool to design target-specific primers for polymerase chain reaction. BMC Bioinfo. 134:1-11. 